\title{
nature
}

4 April 2002 Volume 416 Issue no 6880

Media studies for scientists

Science, with its inherent uncertainties, can be hard to put across to the public. But blaming 'sloppy' journalism is too easy. If researchers are to make their points effectively, they should learn more about how the media work.

$\mathrm{N}$ o organization likes to feel the pressure of negative media coverage. Last year, when the Fred Hutchinson Cancer Research Center in Seattle was accused of mismanaging clinical trials, this bastion of the medical establishment found itself under an unwanted spotlight. Now the series of articles that made the allegations is a contender for the Pulitzer Prize, and those involved are reliving their media nightmare (see page 463).

Leading researchers and scientific bodies have rallied round the centre. This was bad journalism, say the critics. It seems like a familiar story: sloppy journalists misrepresent science.

How often does this happen? The cancer-centre story is a complicated and emotive one. But there is no doubt that science is, on occasion, badly covered in the media. Last week, for instance, one British newspaper ran a front-page story headlined "Scientists find Prozac 'link' to brain tumours". The lead author of the research told Nature that the story was "scandalous" — there is no epidemiological link. His study merely showed that the antidepressant could, in the test tube, prevent certain tumour cells from being triggered to commit suicide by the neurotransmitter serotonin.

But such examples are the exception. In the United States, for instance, media coverage of climate change has been thorough, explaining the consensus view while noting dissenting voices.

In Britain, newspapers, including the one that carried the Prozac story, have produced some excellent science journalism. Much of the coverage of a recent public scare over the safety of the combined measles, mumps and rubella vaccine, for instance, stressed that most experts regard the vaccine to be safe, and pointing out the limitations of the small studies that have linked it to the development of autism. Even the Prozac story qualified the nature of the 'link' further down the piece. Take away the inflammatory headline, and the prominent positioning in the paper, and the story may have caused little fuss.
Nevertheless, many scientists are quick to attack the media when they believe they have been misrepresented. And at conferences addressing the public understanding of science, journalists are often portrayed as the root of the problem.

This knee-jerk reaction itself misrepresents the way in which stories enter the media - journalists are not the only players. University press offices, in particular, must take some responsibility for hyped findings. Pushed by university leaders to maximize total coverage, press officers fill their releases with claims of significant breakthroughs. Scientists then complain when their work is hyped beyond its true worth.

Researchers could also examine how other professions manage the media. Politicians are misrepresented more frequently and significantly than scientists. But they know that attacking journalists is a short-sighted strategy. Instead, they have become experts in rebutting inaccurate stories and imparting their own message.

How far should scientists go down this road? Scientists, as with almost every other profession, enjoy more public trust than politicians. Gaining a reputation for spin could damage this. Researchers should, however, learn what the media wants. Politicians understand the kind of stories that journalists are looking for. If more scientists did too, they would be better equipped to get their message across.

Some progress has already been made in this direction. Many grant-awarding bodies now promote media training for scientists. Britain's Engineering and Physical Sciences Research Council, for example, recently announced plans to include $\mathfrak{E} 500$ (US\$720) for media training in each grant it awards.

Better-funded initiatives of this sort are needed, and inaccurate reporting should not go uncorrected. But attacks on journalists often sound bitter, and have little long-term benefit. Rather than shooting the messengers, scientists should take them to one side and give them the real story.

\section{Prevention remains the best medicine}

\section{For the foreseeable future, smoking will kill more people than cancer researchers can hope to cure.}

A $\mathrm{fter}$ decades of research into the biology of cancer, it is good to finally see some signs of a therapeutic pay-off (see page 470). But the statistics of cancer mortality still make depressing reading. All the more so given that, in major Western countries, tobacco plays a part in one-third of cancer deaths - mainly, but not exclusively, through lung cancer.

This vast toll underlines the continued importance of prevention and especially of campaigns to reduce smoking - in the war on cancer. Stopping the relentless promotional activities of tobacco companies would be a major step forward.

But our imperfect world is home to conflicting political and economic forces. In Europe, for example, the European Commission gained some responsibility for public health with the 1993 Maastricht Treaty, and has an active anti-smoking policy. Yet the European Union spends around 1 billion euros (US\$900 million) each year subsidizing tobacco farmers, three-quarters of whom are in Italy and Greece; Spanish and French farmers receive most of the remaining subsidies. In total, the handouts are broadly comparable to the amount spent annually on cancer research in Europe's public sector. The European Commission wants to phase out the subsidies, which have their historical roots in the European Union's outmoded Common Agricultural Policy, but is facing resistance from some of the member states that benefit.

Researchers are not above these messy conflicts. A proposed European Union directive to restrict tobacco advertising is now being hotly debated, while scientists continue to accept the patronage of Philip Morris, the world's largest tobacco company, which awards a prestigious and generous research prize in Germany every year (see Nature 410, 725; 2001).

Given the centrality of the war on cancer to public health, we should all be asked: which side are you on? 